\title{
Bending Test Galvalum Cold Formed Steel Beam With Variation Mortar and Reinforcement Bars
}

\author{
Fadhila Firdausa ${ }^{1, *}$ Sri Rezki Artini ${ }^{1}$ Ahmad Syapawi ${ }^{1}$ Puryanto ${ }^{1}$ \\ ${ }^{1}$ Civil Engineering Polytechnic of Sriwijaya \\ *Corresponding author. Email: fadhilafirdausa@polsri.ac.id
}

\begin{abstract}
Cold formed steel is a material is often used for construction roofs. The advantages of cold formed steel and its large tensile resistance have attracted interest to developing research make cold formed steel as a beams. Galvalum is a type of cold formed steel. Galvalum consists of galvanis material and aluminium. However, cold formed steel has a weakness against compressive forces so filler materials is a needed. The filler used in this research is a mortar with variation the ratio of cement to sand 1:1,1:2,1:3,1:4. Another factor that increases the bending test is the addition of reinforcement bar to the beam which is intended as a beam stiffener. In this research used reinforcement bar formed by the cold formed steel profile itself with variations of reinforcement bar of 2, 3, 4, and 5. From the results of the mortar compressive strength test, the greatest compressive strength was obtained by 1: 1 mortar variation. The addition of sand to the mortar caused the compressive strength of the mortar to decrease. From the results of bending test, it was found that the smallest deflection value with the maximum load resistance, and the maximum stress and strain were obtained by the cold formed steel beam with the most reinforecement bar and 1:1 mortar variation. From the research results, cold formed steel beams can be used as non-structural beams. For further research, further development is needed and is expected to be able to produce a greater load so that cold formed steel beams can be used as structural beams.
\end{abstract}

Keywords: Bending Test, Galvalum Cold Formed Steel Beam, Variation Mortar, Variation Reinforcement Bar

\section{INTRODUCTION}

Cold formed steel is a construction material that is often used in roof construction. In this research we made a development for cold formed steel beam. We knows that cold formed steel is weaknes to bending test. However, one of the weakness of cold formed steel profile is that it is weak against bending forces that effect is instability of the specimen [1]. So to resolving that cold formed steel beam is filled with mortar. Mortar is a filler material that is often used in construction. Mortar is a mixture of cement, sand, and water [2]. Mortar is a filler that is often used in construction because it resistance to compression tests. There are several types of cold formed steel, including galvalum, galvanis and aluminium. Galvalum is one of the composed materials cold formed steel. Galvalum is consist by galvanis and aluminium. In this research the purpose is to bending test strength of galvalum cold formed steel which is grouted by mortar.
Several literature reviews that have been researched and used as a theoretical basis in this study are as follows; (i) Cold formed Steel Concrete Beams [3] This paper tried to analyze and compare those experimental programs. The comparison showed that the cold-formed steel beam with normal weight concrete gave higher load capacity than the cold-formed steel beam with light weight concrete. However, if the comparison was taken with respect to the ratio of compressive strength to density, the cold-formed steel beam with light weight concrete might give more promising bending elements for earthquake resistant building. (ii) Experimental Analysis On The Behaviour Of Cold Formed Steel Beams Filled With Concrete [4]. This paper is talking about behavior of cold formed steel channel section beams with an grouting with concrete. The purpose this paper is divided in to two distinct phases of activity. In the first activity, the Properties of materials were studied and the second activity is experimental were conducted on ingredients and analyses the mix design of concrete. (iii) Behavior of Concrete/Cold Formed Steel 
Composite Beams: Experimental Development of a Novel Structural System [5]. This research is talking about use hot-rolled steel sections to building industrial construction, such as steel angles or hollow structural section tubes. And the results of this research is indicate that Cold Formed Stell composite flexural elements are feasible and can be modeled with reasonable accuracy. (iv) Behaviour Experimental Investigation Of A ThinWalled Steel Square Hollow Secton Beam Affected By The Interaction Of Concentrated Compressive Load And Bending Moment. [6] This paper is talking about developing a strength analytical method of a thinwalled steel square pipe (Square Hollow Section/SHS) affected by the interaction of concentrated-compressive load and bending moment that its based on plastic mechanisms and elastic theories (cut-off strength), and its accuracy will then be verified by data obtain from an experimental approach. This results is analyzed by using of existing code design namely British Standard (BS 5950 Part 5 1987) of experimental and strength analysis by design code are accurate enough.

\section{RESEARCH METHODOLOGY}

Research methodology that used in this research can be explain with figure 1 .

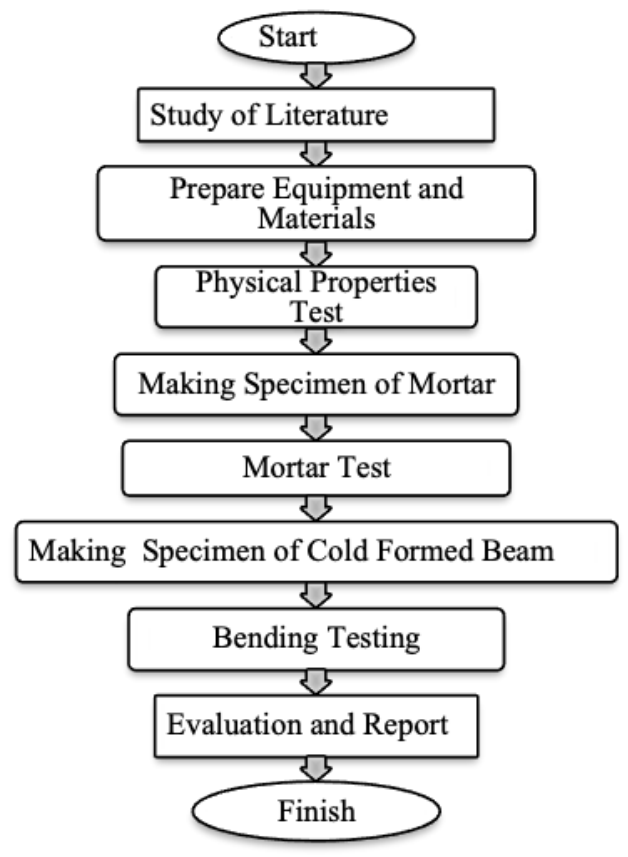

Figure 1. Research Methodology

In this research, mortar variations used a ratio of cement and sand 1:1,1:2,1:3,1:4 where the ratio of cement is 1 and sand 2, 3 and 4 for more details, it can be seen in the following table

Table 1. Variation Mortar Test

\begin{tabular}{c|c|c}
\hline No. & Mortar Variation & Day \\
\hline 1. & $1: 1$ & 28 \\
\hline 2. & $1: 2$ & 28 \\
\hline
\end{tabular}

\begin{tabular}{l|l|l}
\hline 3. & $1: 3$ & 28 \\
\hline 4. & $1: 4$ & 28 \\
\hline
\end{tabular}

Variations of cold formed steel fillers using variations in the ratio of mortar and reinforcement bar, for more details can be seen in the following table

Table 2. Variation Bending Galvalum Test Cold Formed Beam

\begin{tabular}{c|c|c|c} 
No. & $\begin{array}{c}\text { Variation } \\
\text { Mortar }\end{array}$ & $\begin{array}{c}\text { Variation } \\
\text { Reinforcement Bar }\end{array}$ & Day \\
\hline 1. & $1: 1$ & 0 & 28 \\
\hline 2. & $1: 2$ & 0 & 28 \\
\hline 3. & $1: 3$ & 0 & 28 \\
\hline 4. & $1: 4$ & 0 & 28 \\
\hline 5. & $1: 1$ & 3 & 28 \\
\hline 6. & $1: 2$ & 3 & 28 \\
\hline 7. & $1: 3$ & 3 & 28 \\
\hline 8. & $1: 4$ & 3 & 28 \\
\hline 9. & $1: 1$ & 4 & 28 \\
\hline 10. & $1: 2$ & 4 & 28 \\
\hline 11. & $1: 3$ & 4 & 28 \\
\hline 12. & $1: 4$ & 4 & 28 \\
\hline 13. & $1: 1$ & 5 & 28 \\
\hline 14. & $1: 2$ & 5 & 28 \\
\hline 15. & $1: 3$ & 5 & 28 \\
\hline 16. & $1: 4$ & 5 & 28 \\
\hline
\end{tabular}

\section{RESULTS PHYSICAL PROPERTIES TESTING}

In this research cement materials that used is cement type portland 1 and fine aggregate materials that used from Tanjung Raja, Ogan Ilir Regency, Sumatera Selatan. Based on the results of testing the consistency of cement meet the requirements of SNI 15-2049-2004 [7] with a reduction of $11 \mathrm{~mm}$ with a water content of $24 \%$. The amount of water has meet the standard where the amount of water to reach the normal consistency of cement ranges from $22 \%-28 \%$.

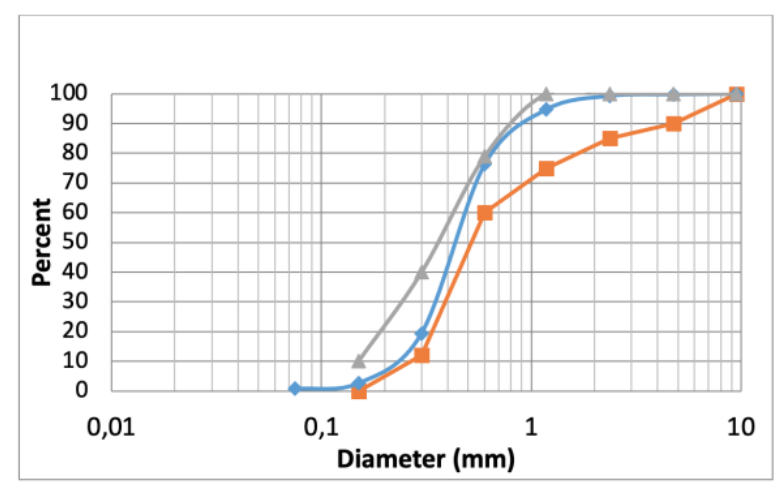

Figure 2. Physical Properties Test Fine Aggregate Materials

The cement binding time test took 104.5 minutes with the test method fulfilling the SNI 15-2049-2004 requirements [7]. The specific gravity test for type I 
portland cement is $3.09 \mathrm{gr} / \mathrm{m} 3$. The cement density value has meet the standard value. The standard value for cement density is $3.0-3.2 \mathrm{gr} / \mathrm{m} 3$.

From the test of bulk density of fine aggregate obtained an average value of $2.15 \mathrm{gr} / \mathrm{m} 3$ and specific gravity of Saturated Surface Dry (SSD) an average value of $2.21 \mathrm{gr} / \mathrm{m} 3$ based on SNI 03-1970-1990 [8] According to SNI 03-1968-1990 [9], the results of the fine aggregate sieve analysis are included in zone 3 as shown in Figure 2.

\section{RESULTS OF MORTAR COMPRESSIVE TEST}

After testing the physical properties materials, the next step is to make the mortar specimen. The mortar specimen that has been 28 days old then tested for the compressive strength. The mortar compressive strength test can be seen in the following figure 3 and according to the regulations SNI 4154:2014 [10]

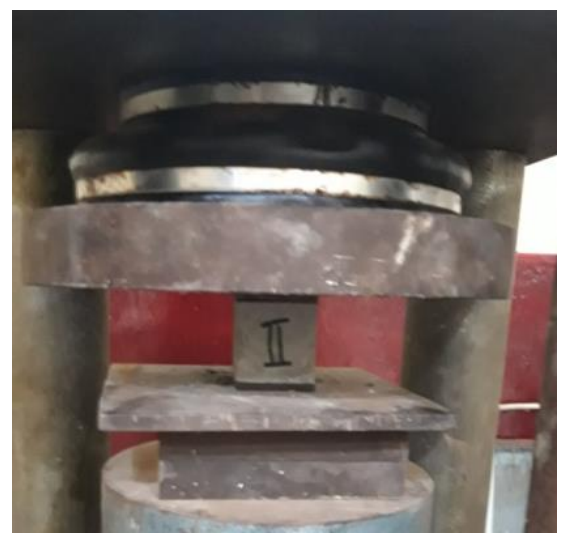

Figure 3. Mortar Compressive Test

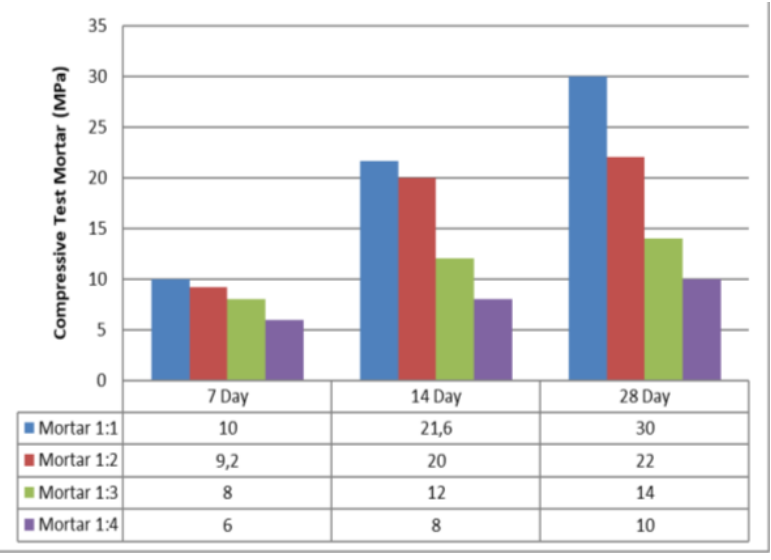

Figure 4. Result of Mortar Compressive Test

\section{RESULTS OF BENDING TEST COLD FORMED STEEL BEAM}

The next step is make a galvalum cold formed steel beam specimen. In the manufacture there are 16 specimens based on variations of mortar and reinforcement bars. Each variation is made with a minimum of 3 specimens with the assumption to avoid errors in getting the test results, which are then averaged so that it will become the final value in the test. Bending test method can be seen in the following figure 5 and according to the regulations SNI 4154:2014 [11]

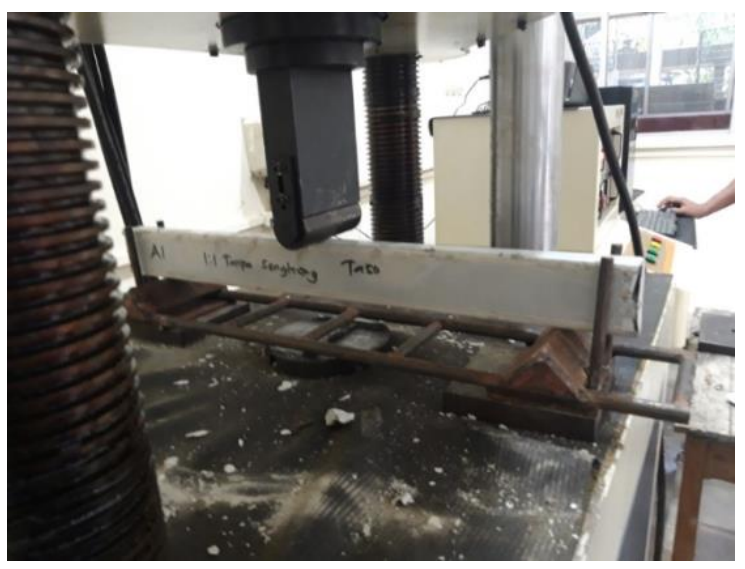

Figure 5. Bending Test Cold Formed Beam

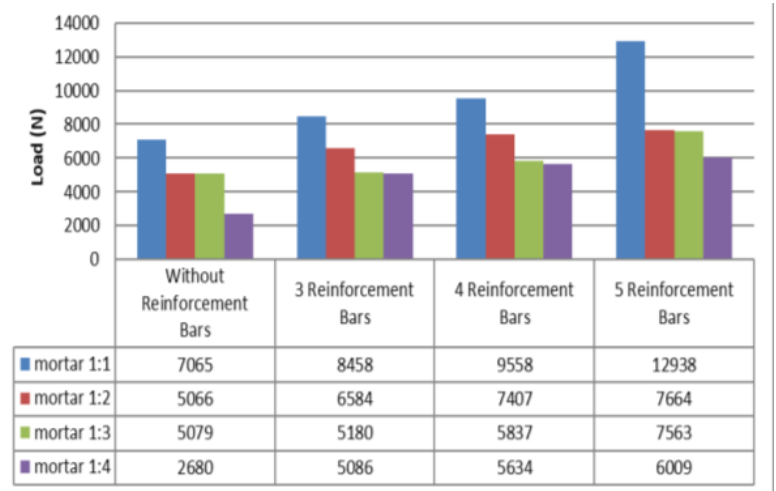

Figure 6. Result of Load Test

From the test results it can be concluded that the load with the maximum yield can be held by a beam with 5 reinforcement bars and mortar with a ratio of 1 : 1. This results shows that the more reinforcement bars used make the greater load resistance being held and the greater the ratio of mortar used make the smaller load that can be held. 


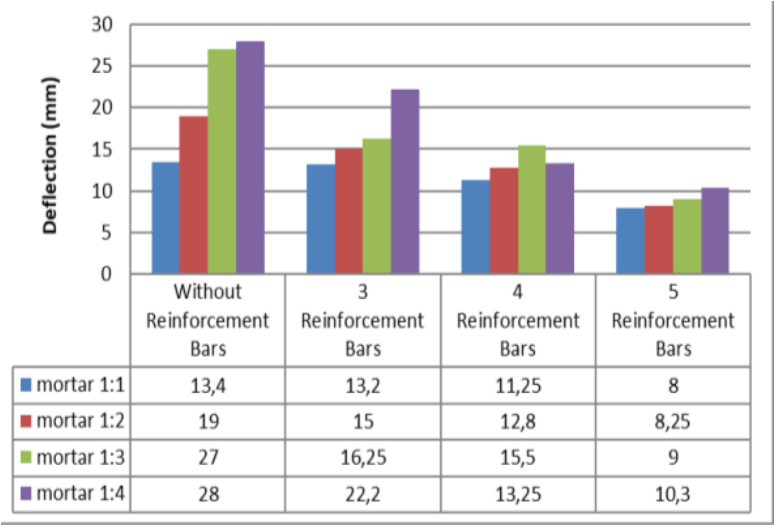

Figure 7. Result of Deflection Test

From the test results that deflection with the minimum value can be held by a beam with 5 reinforcement bar and mortar with a ratio 1: 1 . This results shows that more reinforcement bars used make the deflection is smaller and greater the ratio of mortar used make the deflection is greater.

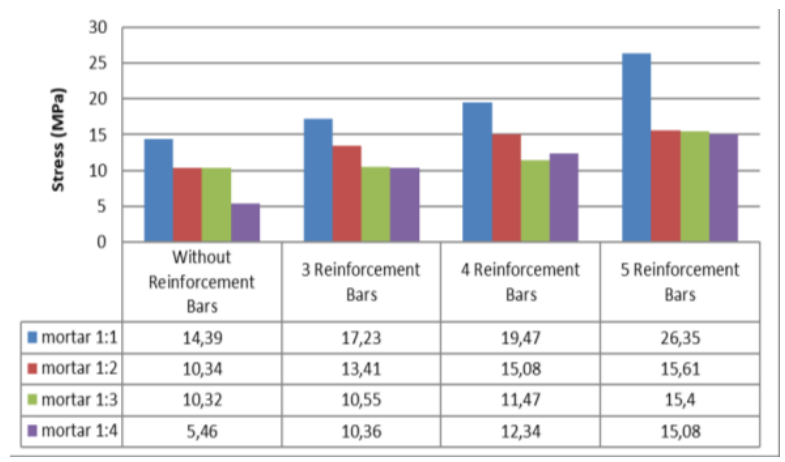

Figure 8. Result of Stress Test

From the test results, it is found that the greatest stress can be obtained by a beam with 5 reinforcement bar and mortar with a ratio of 1: 1 . This results shows that more reinforcement bars used make the stress is greater and greater the ratio of mortar used make the stress is smaller.

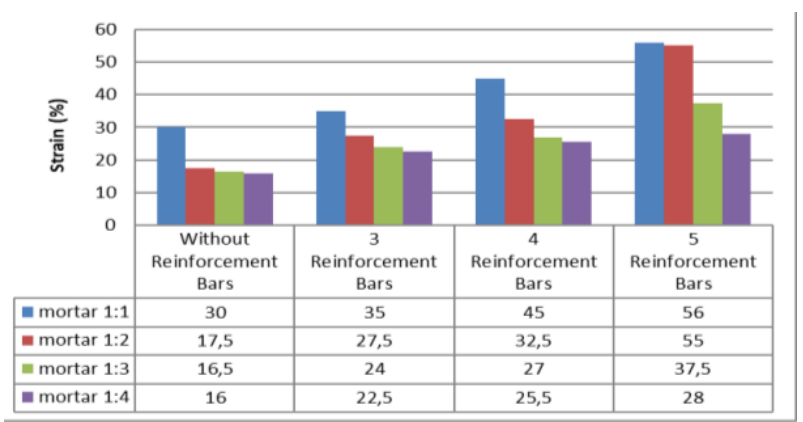

Figure 9. Result of Strain Test

From the test results, it is found that the greatest strain can be obtained by a beam with 5 reinforcement bar and mortar with a ratio of 1: 1 . This results shows that more reinforcement bars used make the strain is greater and greater the ratio of mortar used make the strain is smaller.

\section{CONCLUSION}

The conclusion can be drawn after make this research is the galvalume cold formed steel beam can be used as a beam with a maximum load is $12938 \mathrm{~N}$ with 1: 1 a mortar variation and 5 pieces of reinforcement bars. From the research results, cold formed steel beams can be used as non-structural beams. For further research, further development is needed and is expected to be able to produce a greater load so that cold formed steel beams can be used as structural beams.

\section{ACKNOWLEDGMENTS}

I would like to appreciate Polytechnic of Sriwijaya is fund assitance this research from early until this paper is published.

\section{REFERENCES}

[1] Agus Setiawan, Perencanaan Struktur Baja Dengan Metode LRFD, Jakarta, 2008:18

[2] Felisa Octaviani, dkk., Pengujian Kuat Tekan Mortar dan Beton Ringan Dengan MenggunakanAgregat Ringan Batu Apung dan Abu Sekam Padi Sebagai Substitusi Parsial Semen, Vol. 4, Jurnal Sipil Statik, 2016:2337-6732.

[3] Ade Lisantono, Haryanto Yoso Wigroho, Meita Ratna Sari, "Cold Formed Steel Concrete Beams", Jurnal Teoretis dan Terapan Bidang Rekayasa Sipil, Vol. 19 No 2 August 2012, 7 pages, ISSN 0853-2982

[4] Lenin Muthu Olivu.M, Jose Ravindra Raj.B, "Experimental Analysis On The Behaviour Cold Formed Steel Beams Filled With Concrete", International Journal Of Engineering Sciences And Research Technology, May 2018, 9 pages, ISSN 2277-9655

[5] Nadim Wehbe, Pouria Bahmani, Alexander Wehbe, "Behavior Of Concrete/Cold Formed Steel Composite Beams Experimental Development Of a Novel Structural System" International Journal of Concrete Structures and Materials, Vol. 7, No. 1, PP 51-59, March 2013, ISSN 19760485

[6] Andi Muhdiar Kadir, Dedi Priadi, Eddy S. Siraj, Harkali Setiyono, "Behaviour Experimental Investigation Of A Thin Walled Steel Square Hollow Section Beam Affected By The Interaction 
Of Concentrated Compressive Load And Bending Moment", Majalah Metalurgi, Vol. 28.1.2013, 3348 pages, ISSN 02163188

[7] Standar Nasional Indonesia 03-1968-1990. "Metode Pengujian Tentang Analisis Saringan Agregat Halus dan Kasar".Badan Standarisasi Nasional.

[8] Standar Nasional Indonesia 03-1970-1990. "Metode Pengujian Berat Jenis Agregat Halus".Badan Standarisasi Nasional.
[9] Standar Nasional Indonesia 15-2049-2004." Semen Portland". Badan Standarisasi Nasional.

[10] Standar Nasional Indonesia 4154:2014. "Metode Uji Kekuatan Lentur Beton (Menggunakan Balok Sederhana Dengan Beban Terpusat Di Tengah Bentang)", Badan Standarisasi Nasional.

[11] Standar Nasional Indonesia 03-6882-2002. "Uji Kuat Tekan Mortar", Badan Standarisasi Nasional. 